\title{
IS THE JUDICIAL ROLE JUST A DESCRIPTIVE SOCIAL FACT?*
}

¿ES EL PAPEL JUDICIAL SÓLO UN HECHO SOCIAL DESCRIPTIVO?

Vinicius FAGGION**

\section{Resumen:}

El libro Moral Combat: The Dilemma of Legal Perspectivalism, de Heidi Hurd, intenta determinar el ámbito de las obligaciones morales en la toma de decisiones judiciales, y llega a una conclusión escéptica sobre moralidades relacionadas con papeles. Continuaré esta discusión relacionando las tesis de Hurd con tres teorías conocidas sobre obligaciones de papales. En seguida, argumentaré qué papeles profesionales en sí mismos no pueden generar obligaciones morales. Y, finalmente, explicaré cómo otra teoría puede explicar mejor la relación entre papeles judiciales y obligaciones morales de una manera no constitutiva.

\section{Palabras clave:}

Obligaciones de papeles; dilemas morales; razones prácticas; decisiones judiciales.

\section{Abstract:}

Heidi Hurd's Moral Combat: The Dilemma of Legal Perspectivalism addresses the scope of moral obligations on judicial decision-making and reaches a skeptical conclusion regarding role-relative moralities. I carry forward the discussion putting it in contact with three known theories of role obligations. Then I proceed to argue that professional roles cannot generate moral obli-

*Artículo recibido el 20 de julio de 2019 y aceptado para su publicación el 25 de septiembre de 2019.

${ }^{* *}$ Law Faculty, Federal University of Minas Gerais, Belo Horizonte, Brazil. Contact: vsfaggion@ufmg.bry vsfaggion@gmail.com. 


\section{VINICIUS FAGGION}

gations on their own. And finally, I will explain how another theory can better explain the relationship between the judicial role and moral obligations in a non-constitutive fashion.

\section{Keywords:}

Role Obligations; Moral Dilemmas; Practical Reasons; Judicial Decision-Making. 
Summary: I. Roles and Moral Reasons. II. Three Divergent Sides. III. The Problems of the Generative Approaches. IV. The Social Fact Outlook of Roles. V. Acknowledgments. VI. References.

\section{Roles AND MoRAl REASONS}

In this essay, I suggest that voluntary roles in general and the judicial role, in particular, cannot create or change moral obligations. ${ }^{1}$ This claim entails that these types of roles might be just descriptive social facts. I address the topic in two main steps:

First, I will try to aid the apparently counter-intuitive idea that everyday professional roles cannot alter moral reasons for action. I will pay special attention to the judicial role. The arguments will show that role-relative morality is misconceived and maybe does not exist at all. ${ }^{2}$ More specifically, the argument will show that the idea that there are various moral standards for various kinds of professionals is inaccurate. This has some interesting implications. For example, if, as it were, role-relative morality is a myth, the following two propositions cannot both be true: (i) a citizen $\mathrm{S}$ is morally permitted to break a law $\mathrm{L}$ in a context $\mathrm{C}$; (ii) a judge is morally permitted to punish $\mathrm{S}$ in $\mathrm{C}$ for breaking L. Hence, judicial ethical conduct cannot ascertain as morally correct verdicts that are contrary

1 There are roles that presumably impose obligations independent of our will, like familial roles and there are roles whose obligations can only be acquired from our choices. Therefore, we can argue that we are born with a filial role obligation, but we cannot assert that one was already born with a judicial obligation, because an agent can only acquire judicial obligations by choosing to become a judge. I will restrict my analysis only through role obligations of the voluntary kind. After all the judicial role seems to be a trivial instance of it. For an articulated discussion of types of roles and some concerns about grounding obligations in contractual and noncontractual roles, see Michael O. Hardimon, "Role Obligations" (1994) 91 The Journal of Philosophy 333.

2 Heidi M Hurd, "Justifiably Punishing the Justified" (1992) 90 Michigan Law Review 2203, 2225; Heidi Hurd, Moral Combat: The Dilemma of Legal Perspectivalism (1st edition, Cambridge University Press 1999) 298. 
to reasons justified by ordinary morality, or to state differently, by our critical morality.

Second, I will lay out three accounts of role obligations and show why one of them seems more plausible than the others.

\section{Three DiVERGENT SiDES}

The debate around the possibility of roles operating as sources of moral obligations is currently split into three accounts: the Strong Role-generation Thesis; the Weak Role-generation Thesis; and the Norole-generation Thesis. ${ }^{3}$

The first and second ones assert that professional roles can create or change moral obligations. They are, as it were, "generative approaches". ${ }^{4}$ The last one holds that roles cannot constitute moral obligations. Roles are at best repositories of moral obligations.

In what follows, I further develop these accounts and clarify what they entail.

\section{The Strong Role-Generation Thesis}

The strong and the weak thesis hold two claims:

(1) Roles instantiate moral duties tailored by specific functions that some professionals are expected to perform; ${ }^{5}$

3 This designation was inspired by two terminologies employed by Alan H Goldman, Moral Foundations of Professional Ethics (1st Edition, Rowman \& Littlefield Publishers 1990); and Sareh Pouryousefi, "A Normative Model of Professionalization: Implications for Business Ethics" (Doctorate Thesis, University of Toronto 2013).

4 "Roles characteristically claim to generate moral prescriptions that vary from professional role to role.... Arthur Isak Applbaum, Ethics for Adversaries (1st edition, Princeton University Press 2000) 10.

5 A very popular reference of this idea was articulated by Hardimon (n 1) 334: " $a$ «role obligation» is a moral requirement, which attaches to an institutional role, whose content is fixed by the function of the role, and whose normative force flows from the role" (emphasis added). Hardimon's definition can be used by strong and weak rolegeneration theorists to defend their point, although I believe that Hardimon's role 
(2) Role obligations take precedence for role-occupiers over other moral reasons in cases of conflict.

The difference between the strong and the weak thesis is on how the moral obligations that roles instantiate should prevail on our practical reasoning.

With regards to (1), although roles may ground moral obligations, this implication might not be so easily championed. We need to start from a less contentious assertion that roles generate occupational standards of their own.

Thus, for example, physicians typically are the only ones charged with prescribing medicines to human patients and only teachers are expected to grade students fairly. ${ }^{6} \mathrm{~A}$ similar point can be made about the judicial role. Except for cases decided by a jury, ${ }^{7}$ judges, singly or collegially, typically occupy the sole function responsible to reach legal verdicts. Hence, role-occupations can, but need not, generate moral obligations. What happens is that we usually talk about the duties or obligations of a role, and our usage can either instil, or hold a claim that they are also moral. ${ }^{8}$ Moreover, when we talk about role obligations, we can easily jumble or slip too quickly from indications to vindications. I will not propose that we just stop talking about "duties" or "obligations", but we need to better qualify the terms. ${ }^{9}$

At this level of inquiry, I think John Simmons' idea of positional duties will do the trick: they are "tasks or performances which are

theory in its entirety would be more in line with the weak version. Later, when I examine the plausibility of these two theories, I hope to clarify this point better.

6 David Luban, "Professional Ethics", A Companion to Applied Ethics (1st edition, Wiley-Blackwell 2007) 585.

7 But even here judges typically have the function to seal the decision made by the jury and have, in particular circumstances, the exceptional power to overturn a guilty verdict, e. g., in cases of insufficient evidence being presented at trial by the prosecution.

${ }^{8}$ For an elucidation on how the notions of duty or obligation do not necessarily imply a commitment about how we ought to act morally, see H. L. A. Hart, "Positivism and Separation of Law and Morals" (1958) 71 Harvard Law Review 613; H. L. A. Hart, The Concept of Law (2nd edition, Oxford University Press 1997) 203.

9 I use "duty" and "obligation" interchangeably throughout the essay. 
intimately connected with some particular office, station, or role which an individual can fill". ${ }^{10}$ Note that this definition suspends judgment towards the moral character of the occupational standard. For now on, "role obligation" will represent a positional duty. After all, this idea still carries a presumption about what the role-player ought to do morally. Besides, the possibility of role obligations being moral is precisely what is at stake here.

As for the second claim, if (1) is correct, then (2) may reveal a conflict between role obligations or between a role obligation and general moral obligations. ${ }^{11}$ I will put the former conflict aside and focus on the latter. Sometimes someone who occupies a role seems to lack permission to perform an action only because she occupies that role. However, is that impression justified? This type of question represents the crux of the debate faced by professional ethics, and various ethical dilemmas spring from practice.

The ethical dilemmas around the lawyer's role are the most notorious. ${ }^{12}$ However, the judicial dilemma is the one that interests us. ${ }^{13}$ Hurd formulated a case that puts to the test the role-relative morality of judges. Here is the case: Mrs. Smith, a wife frequently beaten by her husband, justifiably believes that the killing of her violent husband is the only way to save herself and her children from keeping on living a miserable life. She ends up killing the husband and, as a result, the state charges her with homicide. We have strong reason to believe that her act was morally justified, even acknowledging that the offense is an inexcusable case of self-defense. ${ }^{14}$ If this is

10 John A. Simmons, Moral Principles and Political Obligations (Princeton University Press 1981) 12.

11 Albeit implicitly stated, the conflict is being analyzed at an interpersonal level.

12 For a recent take on the lawyer's role, see Tim Dare, The Counsel of Rogues?: A Defence of the Standard Conception of the Lawyer's Role (1a. ed., Routledge 2016); and Michael Huemer, "Devil's Advocates: On the Ethics of Unjust Legal Advocacy" in Emily Crookston, David Killoren and Jonathan Trerise (eds.), Ethics in Politics: the Rights and Obligations of Individual Political Agents (Routledge, Taylor \& Francis Group 2017).

13 It is also easy to imagine the emergence of ethical dilemmas in the roles of physicians, psychiatrists, and businesspersons.

14 Heidi Hurd, Moral Combat (n 2) 10-11. 
the case, what should the judge responsible for the judgment do? It appears the judge has a professional role obligation, which requires him to apply the law and condemn Smith for the felony, even if the judge believes that the wife did the right thing. ${ }^{15}$

The example calls into question a truism about the judicial function, namely that judges have, all-things-considered, a moral obligation to apply the institutional rules of their respective legal systems. ${ }^{16}$

When facing professional dilemmas, the strong thesis states that role-agents are morally obliged by the norms that constitute their occupation. Professional codes of conduct create a new moral environment and the agent's ethical conduct is judged within their domain. ${ }^{17}$ Despite not needing to do so, supporters of the theory also seem comfortable to endorse some kind of moral relativism, namely

15 Another example that appears to fit the bill was made by Alan H Goldman, Practical Rules: When We Need Them and When We Don't (1st edition, Cambridge University Press 2001) 43: a poor old widow did not have sufficient income to pay the rent for the only dwelling place of hers. Her financial downfall was caused by no fault of her own and now she is being sued by a millionaire real estate company claiming the eviction of the house. Assuming that the widow had done nothing wrong to deserve the eviction, besides the violation of a contractual legal right, it appears that a judge can have a moral obligation to violate the civil law and correct the unjustified outcome. For a batch of other morally suboptimal cases, see Jeffrey Brand-Ballard, Limits of Legality: The Ethics of Lawless Judging (1st edition, Oxford University Press 2010) 74-91.

16 "One intuitive way to justify the above model of judicial reasoning is to claim that judges have a moral obligation to apply the law: what I will call an obligation of fidelity. A moral obligation of fidelity would, in effect, preempt the introduction into judicial reasoning considerations heterogeneous to the content of the law and its impartial application. If judges generally have a powerful moral reason to be in fidelity, then they can normally ignore moral concerns that are not legally recognized, since their obligation would usually outweigh or otherwise invalidate competing considerations". Anthony R Reeves, "Do Judges Have an Obligation to Enforce the Law?: Moral Responsibility and Judicial-Reasoning" (2010) 29 Law and Philosophy 159, 160.

17 Another way to express this argument was made in the so-called Separatist Thesis: "the separatist thus upholds a removal of his own specific professional-role morality from all or many other moral requirements of rights or other values; he denies that the latter may counterbalance or outweigh the former". Alan Gewirth, "Professional Ethics: The Separatist Thesis" (1986) 96 Ethics 282, 284. 
a relativism according to which some moral rights, obligations, or permissions are relative to roles. ${ }^{18}$

Thus, the strong thesis splits our moral reasoning between rolerelative reasons and general reasons that, arguably, applies to everyone. However, if this is true, then morality appears to be either a vivid domain of moral strife or a domain of uncertain moral solutions. Professional morality will justify role-occupants to thwart certain interests or outcomes that are permitted by ordinary morality.

\section{The Weak Role-Generation Thesis}

The weak role-generation thesis, also known as the recourse role view, stands as a middle ground between the other two theories. It was developed by Mortimer and Sanford Kadish and further endorsed by Gerald Postema. According to them, a stringent set of occupational standards do not constitute moral requirements. ${ }^{19}$

They assert that voluntary roles were created for a purpose and this purpose is the source of moral obligations related to some role. The recourse role theorists ("role recoursists", for brevity) also deny that professional ethics constitute an insulated normative domain that conflicts with ordinary moral reasoning. Because the ends of the role are the source of moral obligations, the role itself appears to be justified in terms of objective or general moral purposes. Then, if a role's ends are morally justified, every professional decision made with those ends in mind will reflect a role obligation.

18 Alan Goldman appears to be an endorser of this type of theory. However, he asserts that not all roles should be seen as strongly differentiated, although he explicitly claims that the judicial role is a clear-cut example. See Goldman, The Moral Foundations of Professional Ethics (n 3) ch 1-2.

19 “[I]n a recourse role, one's duties and responsibilities are not fixed, but may expand or contract depending on the institutional objectives the role is designed to serve. The recourse role requires the agent not only to act according to what he perceives to be the explicit duties of the role in a narrow sense, but also to carry out those duties in keeping with the functional objectives of the role". Gerald J Postema, "Moral Responsibility in Professional Ethics", Profits and Professions (Humana Press 1983) $37,53-54$. 
The Kadish brothers suggest that when with facing ethical dilemmas, which defies the usual boundaries of their occupation, legal officials can, still acting qua officials, access a wider evaluative standpoint to take a decision that will do justice to the ends of the role. ${ }^{20}$ For example, "judges who nullify the law are not acting lawlessly because the role itself permits this kind of incorporation of ordinary morality". ${ }^{21}$

This account is still a generative approach because the "ends-ofrole heuristic" settles the scope of reasons that the role-player can access to take a professional decision. It is said figuratively that the role grants permission for the agent to think from an all-things-considered evaluative domain. ${ }^{22}$ Thus, the recoursist seems to insist on a curious attachment to the idea that roles themselves provide moral guidance, or that a role can be a sui generis source of moral normativity.

\section{The No-Role-Generation Thesis}

In contrast, the last thesis, also named the nexus view, claims that roles are not sources of moral obligations; they are at best repositories of moral considerations. According to this thesis, there is only one evaluative domain, which can ascribe moral duties to a particular role. Role obligations, as per this view, represent complex instances of general morality; "role morality is not opposed to ordinary morality, but one manifestation of it". ${ }^{23}$ Ultimately, it will be a moral assessment of all available reasons and factual circumstances

20 "In virtue of the nature of the office and its place in the legal system, an official may sometimes be justified, as the official he is, in taking upon himself the decision to depart from some rule of competence and hence from some incurred obligation". Mortimer Kadish and Sanford Kadish, "On Justified Rule Departures by Officials" [1971] California Law Review 905, 906.

21 W. Wendel, "Three Concepts of Roles" [2011] Cornell Law Faculty Publications $547,552$.

22 Pouryousefi (n 3) 214.

23 Judith Andre, "Role Morality as a Complex Instance of Ordinary Morality" (1991) 28 American Philosophical Quarterly 73, 75. 
that will determine what the role-occupier ought to do, all-thingsconsidered.

The general idea is that roles provide epistemic reasons to believe that the assigned-conduct ought to be fulfilled, instead of a practical moral reason to do what the role seems to impose. ${ }^{24}$ For the nexus view, roles might designate another relation, which can be to specify, to aim at, or trigger moral obligations (whose existences are independent of the role). ${ }^{25}$ In other words, as suggested before, roles seem to indicate, rather than vindicate moral obligations. Moreover, because roles can express one of those ideas, the justification of the obligations inscribed in a role is made transparent to moral analysis and is external to the role itself. ${ }^{26}$

\section{The Problems of the Generative Approaches}

Here I claim that, despite having some intuitive pull, generative approaches must be rejected. Consider the following scenario:

While bathing on Lake Beach, Lucky is caught up by the tide. He panics and, for that reason, is unable to swim back to the coast. Unless rescued, Lucky will drown. Emerson is the coast guard of Lake Beach, hired precisely to rescue swimmers in peril. Seeing that Lucky is about to drown, Emerson does what he was hired to do: saving swimmers in peril. Lucky is thus saved. Of course, Emerson does not just do what he was hired for. He also, intuitively, does what he was morally required to do in that situation. Can we say then that

24 For a contrast between reasons for belief and reasons for action, see Hurd, Moral Combat (n 2) 153-83, where she suggests that theoretical authority, a type of epistemic authority, represents the correct account of the reason-giving force of law. She argues that theoretical authorities provide evidential reasons to believe in antecedently existing reasons for action generated by existing moral facts. If we extend this rationale to comprise voluntary roles, we can claim that roles of this kind might specify, aim at, or trigger moral reasons.

25 For an insightful investigation into the nature of epistemic or reason-giving in the triggering sense, see David Enoch, "Reason-Giving and the Law", Oxford Studies in the Philosophy of Law 1 (2011), 1-38.

${ }^{26}$ W Bradley Wendel, "Legal Ethics as Political Moralism or the Morality of Politics” (2008) 93 Cornell Law Review 1413, 1423. 
Emerson's role qua coast guard was the source of the moral obligation to save bathers in peril?

Consider the overly distracted Lucky once more. He is drowning, again, but this time Emerson was not there to save him, Palmer was. But here is the catch: Palmer is not a coast guard; he is a triathlete. He ruminates about the situation and concludes that despite being the only person around he is not obligated to rescue Lucky. Not long after, the unlucky man drowns and passes away. Can Palmer use the fact that he was not hired to save swimmers as an excuse? It does not seem so. Being, in that circumstance, the only person capable to save Lucky, it follows that Palmer was indeed morally obliged to save Lucky. However, if Palmer had the same kind of moral obligation as Emerson, we can conjecture that the professional role of a lifesaver cannot create or alter the moral obligation to rescue drowning bathers. This obligation existed all along. It is a general obligation that we all have in some circumstances: to help those in distress if there is no significant risk to harming oneself in the process. ${ }^{27}$

If I am correct, we cannot argue that the coast guard role adds something to Emerson's moral obligations. Maybe we can say that the role of a coast guard adds more salience or responsibility to an already existing moral obligation. Then, to be a coast guard entails rescuing persons (when it is feasible) without a slight shadow of a doubt. We can also infer that, if the role does not alter one's moral obligations, in being a coast guard the professional acquires new conditions of action; after all, Emerson is hired to preserve safety conditions for bathers. Then, it is imperative that Emerson

27 Someone could argue that if Palmer saved Lucky, his heroism was a supererogatory action and from there insist that the role of a coast guard alters supererogatory reasons into obligatory reasons. But that is weird. If we reason in this way, we will undermine one firmly held conviction about the morality of rescues and be forced to forgive Palmer for his lack of wisdom and moral sensibility. After all, Palmer was an exceptional swimmer so it is perfectly reasonable to expect that he could save lives adrift. This is so because there is a principled reason for rescue already mentioned: the duty to save people in distress if there is no significant risk of harming oneself. Thus, the "this is not my job" excuse seems coarse and morally unjustified. 
remains watchful in his working hours, a positional duty that we clearly cannot demand from swimmers like Palmer.

Enough of Baywatch cases. Let us see if these cases tell us anything significant to the discussion about the judicial role. Right from the get-go, we can pinpoint one dissimilarity:

A triathlete can just jump into the water and save a drowning swimmer. But it is not the case that even the wisest of the moral reasoners can simply sit on the bench and issue a legal decision. Roles like those of the surgeon, lawyer, or judge have confined conditions of occupation. Typically, only experienced and licensed jurists can become judges through a public exam or government nomination. But these formal conditions do not tell us much about the need to perform moral obligations that come to be attached to these roles, they only tell what agent, as a matter of fact, can act as a professional. For that reason, I think we can use a similar rationale from the Baywatch examples to the judicial role, with the caveat that typically only a person invested as a judge can perform the functions of the role and use moral reasoning in adjudication.

My suggestion is that, just like the Baywatch case, there are pressing moral obligations that take part on adjudication, and those obligations exist despite the existence of the judicial role, or even the existence of a legal system. Hence, it is possible that some moral obligations that every person should carry out, being part of a role or not, will appear to be in conflict with the typical understanding we have of professional ethics (as the case of the said moral obligation to apply the law ascribed to judges). Thus, when confronted with a morally suboptimal case, the judge can have a moral obligation to absolve justified offenders, just as a good swimmer can rescue drowning bathers.

I think this gives us an overall reason to dispute the plausibility of the generative approaches. Let us discuss, now, particular objections against the strong and the weak thesis, with the judicial dilemma in mind.

As shown, the strong thesis claims that there are roles with their respective moral obligations, and these should be only evaluated from rules or conventions within the professional realm. I also said that some strong role theorists endorse a version of moral relativ- 
ism. ${ }^{28}$ In virtue of having these commitments, they simply bite the bullet and embrace the judicial dilemma: they see no problem with the opposed conflicts of rights and interests of innocent defendants and the judicial duty to apply the legal system's standards. If the professional tenets of the judicial role lead to this conclusion, so be it.

However, this is too bitter a bullet to bite. If we embrace the dilemma we would be forced to hold that a judge could be morally excused by his professional role to sentence innocent persons because he is so required qua judge. The famous example of the abolitionist judge Joseph Story illustrates this point. He was an opponent of slavery, but nevertheless felt bound by his role as a judge to enforce the current legal standard at the time, the Fugitive Slave Act, which required the restitution of escaped slaves to their masters. In a letter to a friend, he wrote:

I shall never hesitate to do my duty as a Judge, under the Constitution and laws of the United States, be the consequences what they may. That Constitution I have sworn to support, and I cannot forget or repudiate my solemn obligations at pleasure. You know full well that I have ever been opposed to slavery. But I take my standard of duty as a Judge from the Constitution... ${ }^{29}$

${ }^{28}$ Goldman (n 3) 10, for example, grounds the strong theory in a relativism of moral values and suggests that there are systems of values that cannot be evaluated in an objective or value-neutral way. Because of that, it is possible to conceive the emergence of differentiated professional domains with particular ways of acting morally. He states "that there may be two or more self-consistent but mutually incompatible sets of values, such that any preference for one set over the others would pressupose values contained in the first but not in the others. In this situation there could be no value-neutral reason for preferring one of these systems over the others. We could not say that one of them as a whole was more rational or morally superior in some objective sense, since the notion of rationality or moral superiority to which we appealed would beg the question in favor of the one system and against the others. And yet what counted as moral reasons in relation to one of these value systems would not in others; actions judged right from the viewpoint of one such system might be judged wrong from others". Nevertheless, he still finds possible to explain institutional obligations under general principles and to ensure that professionals cannot appeal to ordinary moral considerations when acting qua professionals.

29 Joseph Story, Life and Letters of Joseph Story: Associate Justice of the Supreme Court of the United States, and Dane Professor of Law at Harvard University (The Lawbook Exchange, Ltd 2001) 431. 
Thus, the problem with this account is that the strong thesis appears to create an unbridgeable gap between the putative moral obligations of the role and ordinary moral reasons or critical moral thinking. Joseph Story's confessions show how the idea that judges have a moral obligation to be faithful and to apply the legal systems' standards compels him to condemn justified offenders to a hideous fate. Because he thought he had a role obligation to obey the law he reached a resolution that it was not his responsibility as a professional to reach the correct moral verdict. ${ }^{30}$

The strong theorist can deny this inference, but I think the denial will undermine the idea that there are insulated realms of moral valuation, the realm of professional morality, and the realm of ordinary morality. If we reject that judges have a special obligation of fidelity, because the law is unjust, we are using general and critical moral judgments to argue that judges cannot have moral obligations in these circumstances. However, how can we now maintain the idea that role obligations are justified without an appeal from ordinary morality? The strong thesis is just too strong. It can turn even wicked professional obligations into moral ones. And if we try to soften the undesired consequences, the thesis becomes incoherent.

Now we can see if the weak thesis can escape the objection above.

Because the recoursist uses ordinary morality that captures the role's ends to discover the moral obligations of the professional, he can argue that high fidelity to the legal systems' standards is an in-

30 Richard Wasserstrom, "Roles and Role Morality", in Luban (ed.), The Good Lawyer (Rowman \& Littlefield Publishers, Incorporated, 1983) 28, captures the gist of the matter: "the problem, it seems to me, is that behaviour that is potentially criticizable on moral grounds is blocked from such criticism by an appeal to the existence of the actor's role which it is claimed, makes a moral difference. The appeal to the existence of the role seems to distort, limit, or make irrelevant what might be otherwise morally relevant, if not decisive, reasons for acting or abstaining for acting". This objection has more repercussions that I cannot afford to give its proper treatment here, because it depends on in-depth analysis on questions about the importance of personal convictions and the autonomy of the individual on professional decision-making environments. To additional criticisms about this issue of professional detachment, see Postema (n 19) 73-81 and Applbaum (n 4) 15-42. 
correct picture of judicial obligations. Therefore, the role of the judge has to exist because of a good purpose. So, when confronted by an evil regime or a morally suboptimal legal standard, the judge is not obligated to follow unjust directives. Thus, acting within the role, a judge has the discretion to disobey some decision rules. The recoursist's way out can be expressed by a condition introduced by Hardimon, the reflective acceptability:

To say that a social role is reflectively acceptable is to say that one would accept it upon reflection. Determining whether a given social role is reflectively acceptable involves stepping back from that role in thought and asking whether it is a role people ought to occupy and play. Determining that a given social role is reflectively acceptable involves judging that it is (in some sense) meaningful, rational, or good. ${ }^{31}$

This condition is on par with the recourse view. A normative reflection about the purpose of the role is a way to inquire about its ends. However, the way I see it, the conditional falls flat to explain how roles generate moral obligations. If to recognize the ethical obligations of a role we need to step outside the usual way we perceive its obligations, how the recoursist can plausibly claim that the moral force of those obligations flows from the role itself? When querying if the role obligations of judges are really moral, we are using an external moral point of view. In other words, we are using critical morality in order to identify the moral obligations attached to a role. But if the recoursist asks us to do that, he is undermining his theory because,

If what a role really requires, rather than what it merely appears to require, depends on how it can best serve some independent value, then the normative force of the role would seem to derive from that value. Apparently, according to Hardimon, conventional understandings of the role that cannot be construed as serving the relevant value are not genuine elements of the role and do not give rise to role obligations. The independent value, then, is doing all the work in establishing obligatory force, not the social recognition of the role. ${ }^{32}$

31 Hardimon (n 1) 384.

32 Reeves (n 16) 175. 
Thus, this middle-of-the-road strategy, sensitive towards ordinary morality, makes the weak theory incoherent because the recoursist argues for two incompatible claims: that roles constitute moral obligations; and that the instantiation of these obligations is made from an independent value, detachable from the role.

Another problem is that the recourse role account is too underspecified to solve professional dilemmas. Reflection upon the depths of the judicial role could reveal that its ends frankly entails a commitment to the legal system's values, such as the rule of law; so absolving a justified offender will weaken those values, and judges need to preserve them. Alternatively (and probably what the recourse role theorists aspire) judges could disregard some legal standards on morally suboptimal cases because too much fidelity may produce injustice. So ultimately, the weak thesis collapses into a strong or a no-role-generation thesis.

\section{The Social Fact Outlook of Roles}

Now I dedicate the final section to clarify the nexus view, the theory that I think offers the best explanation of professional roles. I also seek to lay down some of its theoretical and practical advantages.

First, let us recap that for this view, voluntary roles cannot form a moral domain on their own, and this fact implies that moral evaluation is somewhat external to the practice of a role. Thus, it appears that roles do not need to have any necessary moral content. Professional roles are simply what they are, and not what they ought to be. ${ }^{33}$ If this is so, then to identify a role will not be so different from the way legal positivists understands law: as a descriptive social fact. For instance, Hart argued that law exists from a social rule at least accepted by the officials charged with the responsibility to administer it. ${ }^{34}$ So the legal positivist does not need to engage in moral evaluation to recognize law either as coercive or as bind-

\footnotetext{
33 Applbaum (n 4) 10.

34 Hart (n 8).
} 
ing. ${ }^{35}$ Similarly, "the existence and content of no rule of a role depends on its meeting an evaluative standard; rather, the rules of a social role just are those standards that are as a matter of social practice convergently treated as its rules". ${ }^{36}$ Thus, convergent patterns of behavior impute to one assigned-role a set of positional duties or role obligations, which the role-player shall follow.

Not surprisingly, Applbaum made the analogy and called his theory practice positivism. Because social practices are acknowledged by what they are and not for what they ought to be, the positional duties of a role can be subjected to moral criticism and, hopefully, correctly ascertained. Applbaum's theory is on the same page with what has been suggested throughout the essay: that a role cannot generate and impinge one set of moral obligations that differ and interfere with justified reasons for action.

I believe this way of conceptualizing voluntary and professional roles has important advantages in contrast to the available alternatives.

The first one has to do with its clarity. The nexus view allows us to see clearly what professional roles entail before subjecting them to moral criticism. In addition, the theory shows its simplicity, for there is only one moral domain to scrutinize the actions of persons in general and of role-players in particular.

Here a weak role theorist could retort, "Well, our theory equally endorses evaluation from ordinary morality; professional actions just need to reflect the role's ends". The rejoinder is tenable, but then I can devise another layer of simplicity in favor of the nexus view, related to its coherence. Because role recoursists still insist on the constitutive role of the role, their theory loses its grip, because they face problems to explain why perverted roles cannot generate moral obligations. Consequently, they now need additional argu-

35 For a complete analysis on the possibilities of evaluating the law and on how legal positivists do not engage in substantive moral analysis to conceptualize law, see Julie Dickson, Evaluation and Legal Theory (Hart Pub 2001).

36 Stefan Sciaraffa, "Two Perspectives on the Requirements of a Practice" in Maksymilian Del Mar (ed.), New Waves in Philosophy of Law (1st edition, Palgrave MacMillan UK 2011) 215. 
ments to elucidate role obligations as moral. ${ }^{37}$ But, as we saw, arguments like the reflective acceptability turn this generative theory internally incoherent. Hence, by insisting on the now disputed constitutive aspect of roles, the weak theorist accepts a dubious stake to reach the same goal achieved by the nexus view, namely to evaluate role obligations through ordinary morality.

Finally, the nexus view shows the meta-theoretical virtue of comprehensiveness, because its claims make an all-encompassing understanding of the character of voluntary role obligations. It explains that roles can add more salience and responsibilities to the role-player's obligations, even if these roles are good or bad ones. If positional duties reflect a moral requirement, then the role specifies, aim at, or trigger this obligation for the agent. Now, if a positional duty is morally unjustified, the role can still add saliency, but from a different nature. Maybe the agent obeys his role obligations for prudential, self-interest reasons, or reasons of conformity, but these reasons do not bind the agent morally, because they are incapable to trigger moral obligations.

By consequence of these advantages, the No-role-generation Thesis can be a fruitful rationale to solve professional dilemmas properly, such as the judicial one. The theory diminishes an impression regarding morality (one arguably caused by our strong rolerelative attitudes): the tendency to state its conflicting character, as a domain that turns agents into moral gladiators in an arena of disagreement "in which one's moral success would depend on another's moral failure". ${ }^{38}$ When we effectively have only one evaluative domain to analyze the correctness of role obligations, our chances to reach better and less contentious decisions (or verdicts), appears to be facilitated.

Lastly, I would like to conclude with a suggestion that follows from the reasoning built up until here. It seems that the arguments addressed in the essay led me to endorse a normative "external-

37 Role recoursists face difficulties to dispel their "generative aspect" in vile roles like the mercenary or the mafia member. They even seem to be forced to deny that a formalist judge in a perverse legal system is really a judge at all.

38 Hurd, Moral Combat (n 2) 10. 
ist" strategy of role-evaluation. ${ }^{39}$ After all, we saw that probably we need to evaluate the moral obligatoriness of professional directives from a point of view that "appeals to standards beyond the particularities of institutionally specified role obligations". ${ }^{40}$ If this is correct, then perhaps every responsible moral agent needs to distance itself as much as possible from the strictures of a role to reflect critically if its duties imposed are really justified. As Applbaum once said, "judgments about the legitimate authority of a role can and must always be made from a standpoint outside the role, within one's own shoes". ${ }^{41}$ This moral posture appears to be a natural consequence for theorists that think that role-relative morality is a kind of a myth.

\section{ACKNOWLEDGMENTS}

I am indebted to Lucas Miotto for the careful comments in an earlier version of this article and to Thomas Bustamante for the revision. I would like to thank André Coelho, Heidi Hurd, Michael Moore, Ronaldo Macedo, Saulo Mattos, and Thomas Bustamante, all participants of the Colloquium "Legal Obligations and Perspectivalism: Celebrating the 20th Anniversary of the Publication of Heidi Hurd's book "Moral Combat»", held at the Federal University of Minas Gerais in December 2018. I also acknowledge the financial support given by CAPES (Coordenação de Aperfeiçoamento de Pessoal de Nível Superior).

\section{REFERENCES}

Andre J., "Role Morality as a Complex Instance of Ordinary Morality" (1991) 28 American Philosophical Quarterly 73.

39 An "internalist" strategy will sustain that role obligations cannot be assessed by standards outside the practice of the role.

40 Sean Cordell, "Virtuous Persons and Social Roles" (2011) 42 Journal of Social Philosophy 254, 261.

41 Applbaum (n 4) 259. 
Applbaum AI., Ethics for Adversaries (Princeton University Press 2000).

Brand-Ballard J., Limits of Legality: The Ethics of Lawless Judging (1 edition, Oxford University Press 2010).

Cordell S., "Virtuous Persons and Social Roles" 42 Journal of Social Philosophy 254.

Dare T., The Counsel of Rogues?: A Defence of the Standard Conception of the Lawyer's Role (1 edition, Routledge 2016).

Dickson J., Evaluation and Legal Theory (Hart Publishing 2001).

Enoch D., "Reason-Giving and the Law", Oxford Studies in the Philosophy of Law 1 (Social Science Research Network 2011), available in: <https://papers.ssrn.com/abstract=2607030> accessed 27 October 2018.

Gewirth A., "Professional Ethics: The Separatist Thesis" (1986) 96 Ethics 282.

Goldman A.H., Moral Foundations of Professional Ethics (1st U.S. Edition edition, Rowman \& Littlefield Publishers 1990).

Goldman A.H., Practical Rules: When We Need Them and When We Don't (first edition edition, Cambridge University Press 2001).

Hardimon M.O., "Role Obligations" (1994) 91 The Journal of Philosophy 333.

Hart H.L.A., Law, Liberty, and Morality (Stanford University Press 1963).

Hart H.L.A., "Positivism and Separation of Law and Morals" (1958) 71 Harvard Law Review.

Hart H.L.A., The Concept of Law (Penelope Bulloch and Joseph Raz eds, 2nd edition, Oxford University Press 1997).

Huemer M., "Devil's Advocates: On the Ethics of Unjust Legal Advocacy", Ethics in Politics: The Rights and Obligations of Individual Political Agents (Routledge 2017), available in: <https:// www.routledge.com/Ethics-in-Politics-The-Rights-andObligations-of-Individual-Political/Crookston-KillorenTrerise/p/book/9781138858039> accessed 20 May 2018. 
Hurd H. M., Moral Combat: The Dilemma of Legal Perspectivalism (Cambridge University Press 1999).

Hurd H. M., "Justifiably Punishing the Justified" (1992) 90 Michigan Law Review 2203.

Kadish M. and Kadish S., "On Justified Rule Departures by Officials" [1971] California Law Review 905.

Luban D. (ed.), The Good Lawyer: Lawyers “Roles and Lawyers" Ethics (Rowman \& Allanheld 1983).

Luban D. (ed.), "Professional Ethics", A Companion to Applied Ethics (Wiley-Blackwell 2007), available in: <https://onlineli brary.wiley.com/doi/abs/10.1002/9780470996621.ch43> accessed 27 October 2018.

Postema G. J., "Moral Responsibility in Professional Ethics", Profits and Professions (Humana Press 1983) available in: <https://link. springer.com/chapter/10.1007/978-1-4612-5625-0_4> accessed 15 May 2018.

Pouryousefi S., "A Normative Model of Professionalization: Implications for Business Ethics" (Doctorate Thesis, University of Toronto 2013), <https://tspace.library.utoronto.ca/bit stream/1807/70133/3/Pouryousefi_Sareh_201311_PhD_ thesis.pdf $>$.

Reeves A. R., "Do Judges Have an Obligation to Enforce the Law?: Moral Responsibility and Judicial-Reasoning" (2010) 29 Law and Philosophy 159.

Sciaraffa S., "Two Perspectives on the Requirements of a Practice" in Maksymilian Del Mar (ed.), New Waves in Philosophy of Law (Palgrave Macmillan UK 2011) available in: <https://doi. org/10.1057/9780230316645_10> accessed 16 September 2018.

Simmons A., Moral Principles and Political Obligations (Princeton University Press 1981).

Story J., Life and Letters of Joseph Story: Associate Justice of the Supreme Court of the United States, and Dane Professor of Law at Harvard University (The Lawbook Exchange, Ltd 2001). 
Wasserstrom R., "Roles and Morality" in David Luban (ed.), The Good Lawyer: Lawyers' Roles and Lawyers' Ethics (Rowman \& Allanheld 1983).

Wendel W., "Three Concepts of Roles" [2011] Cornell Law Faculty Publications available in: <https://scholarship.law.cornell. edu/facpub/580>.

Wendel W. B., "Legal Ethics as 'Political Moralism' or the Morality of Politics" (September 2008) 1431. 